Journal of Educational

Technology \& Online Learning

Volume 4 | Issue $4 \mid 2021$

http://dergipark.org.tr/jetol

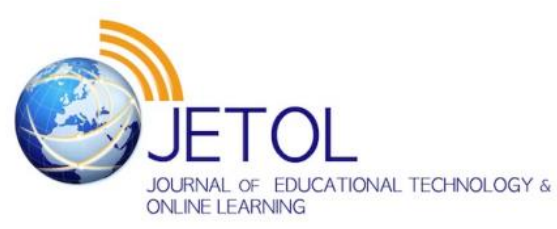

\title{
Covid-19 effects on distance education in higher education: A comparison with bibliometric analysis before Covid-19 pandemic and the Covid-19 pandemic periods
}

\author{
Murat TOPAL $^{\text {a* (D), Aslıhan İSTANBULLU }}{ }^{\text {b }}$ (D), Şirin KÜÇÜK-AVCI ${ }^{c}$ (D) \\ a Sakarya University, Turkey \\ b Amasya University, Turkey \\ c Akdeniz University, Turkey
}

Suggested citation: Topal, M., İstanbullu, A. \& Küçük Avcı, Ş. (2021). Covid-19 effects on distance education in higher education: A comparison with bibliometric analysis before Covid-19 pandemic and the Covid-19 pandemic periods. Journal of Educational Technology \& Online Learning, 4(4), 864-879.

\section{Article Info}

Keywords:

Higher education

Distance education

COVID-19

Pandemic

\begin{abstract}
The Covid-19 pandemic, which emerged in the last months of 2019, spread rapidly and has affected the whole world. The pandemic also affected higher education significantly, and face-to-face education in higher education institutions were suspended. Most universities have changed the teaching method from traditional to online education. Thus, more and more researchers focused on COVID-19 and distance education in higher education. The aim of the research was to examine the impact of the Covid-19 pandemic on higher education studies in the field of distance education. For this reason, the changes in distance education research in the pre-pandemic and the pandemic period were analyzed in terms of some performance variables. Two different meta-data sets, consisting of 1322 articles for the pre-COVID-19 period and 2103 for the COVID-19 period, obtained by querying the Web of Science database, were used for analysis. Vosviewer software were used for bibliometric analysis, while Harzing's Publish or Perish software was used for h-index calculation. Publications from the two different periods were compared according to researcher(s), publication, journal, institution, and country criteria using citation analysis. The citation analysis showed that the most cited researchers of the pre-pandemic period were A.Bozkurt, B. Rienties, and D. U. Bolliger, while the most cited researchers of the post-pandemic period were C. Herodotou, J. C. Bonk and M.Y. Doo. Computer \& Education ranked among the most-cited journal in the pre-pandemic period, while in the post-pandemic period, the most cited journal was Education and Information Technologies The most cited studies in the pre-pandemic period were conducted by researchers working at King Saud University and the University of South Africa, while in the post-pandemic period Universiti Teknologi Malaysia and Indiana University were in the leading position. The results clearly show that Covid-19 has given a new direction to distance education.
\end{abstract}

\section{Introduction}

One of the key challenges in education is maintaining its sustainability, especially during severe crises such as global pandemics (eg SARS, Ebola and COVID-19) or natural disasters (eg Tsunami and Haiti earthquake). A crisis can seriously affect human life and disrupt many daily activities. As a matter of fact,

\footnotetext{
* Corresponding author: Computer Education and Instructional Technology, Sakarya University, Turkey.

e-mail addresses:mtopal@sakarya.edu.tr, aslihan.babur@amasya.edu.tr, sirinavci@akdeniz.edu.tr

This study was partly presented as a proceeding at the 1st International Conference on Educational Technology and Online Learning

Conference held between 22-24 September 2021.
} 
the epidemic negatively affected the international economy, trade, health, education and many sectors. It has also harmed the psychological and emotional health of millions of people, regardless of age, gender, race, ethnicity, and socioeconomic status (Laato et al., 2020). Significant changes have been made in all areas of society to control the spread of the virus (Demirbilek et al., 2020). One of the measures taken to reduce the spread of the pandemic has been the transition to emergency (or remote) distance education by closing schools (Talwar et al., 2021; Demirbilek et al.,2020; Hodges et al., 2020).

Distance education is a longstanding concept in higher education. The extant literature identifies "distance learning" as the learning facilitated using digital tools, contents, and ICTs, which provides a wide spectrum implementation of online interaction and collaboration between the learners and their instructors or peers outside a traditional classroom (Sangrà et al., 2012; Sun et al., 2008). By another definition, distance education is any formal, informal, and non-formal learning activity that are facilitated by information and communication technologies to decrease distance between learners and educators both physically and psychologically to increase interactivity among learners, learning sources and facilitators (Bozkurt, 2019). In fact, it refers to learning through technological devices when there is a physical distance between the learner and the educator. It emerged with a letter to provide education to students who are willing to learn and do not have the opportunity to go to school, and it has maintained its continuity by becoming widespread with the development of technology (Keegan, 1980). In this respect, it is not a new phenomenon. Although distance education activities continued during the epidemic process are perceived as similar to traditional distance education activities, there are great differences between the two processes (Bozkurt, 2020). Considering that the pandemic negatively affects higher education (UNESCO, 2020), the change in the profile of COVID-19's distance education research in higher education before and after the epidemic has been a matter of interest. According to Yavuz et al. (2021), in his study, aimed to reveal the profile of the studies on distance education activities during the Covid-19 period. For this purpose, analyzed 220 articles in Web of Science were examined, using bibliometric analysis. As a result of the analysis, the most used keywords, the most cited journals, the most publishing journals, the most publishing countries, and the most cited authors were evaluated. The study was conducted with a year limitation (March $2020-$ February 2021) and a limited number of (220) articles. Karaköse and Demirkol (2021) examined the relationship between the COVID-19 pandemic and education using bibliometric analysis. The article was evaluated in terms of journal, country and institution, subject, method, study group and data collection tools. Yavuz et al. (2021) revealed the profile of studies on distance education activities during the Covid19 period. In data analysis, bibliometric analysis and content analysis were used. Within the scope of bibliometric analysis, the most used keywords, the most cited journals, the most publishing journals, the most publishing countries, and the most cited authors were examined. In content analysis, methodological trends (method, sample size, data collection tool, data analysis type) used in the studies were examined. Within the scope of the study, 220 studies were examined from the Web of Science database. Elçiçek (2021) used content analysis and categorical analysis in his study in which he examined the trends in scientific articles originating from Turkey regarding distance education during the Covid-19 pandemic period. 125 scientific research articles published in the Google Scholar database until April 2021 were examined in terms of trends, article information, research methods, sample, data collection tools, data analysis methods, and subject. In the study, the year range was limited as (1 January 2020-31 December 2020), and the data set consists of 100 articles. In the studies, the trend of distance education research conducted only during the pandemic period was examined using bibliometric analysis in terms of different variables. In this study, the citation and publication related metrics of researches on distance education in higher education was evaluated before pandemic and the pandemic periods.

The epidemic has led to the increase and diversification of research and applications in the field of pandemic education. Researchers who do research on any subject have difficulty in reaching all the studies on that subject or spend a lot of time to reach them (Goktas et al., 2012). At this point, content and meta-analysis results provide significant convenience to researchers (Selçuk et al., 2014). The bibliometric studies to be 
carried out for distance education activities during the Covid period are considered important in terms of determining the trends and tendencies in this field. Considering that the distance education literature has a multidisciplinary content (Gurcan \& Cagiltay, 2020), it is of great importance to perceive how such a change affects distance education research. It is believed that the data obtained from these studies will make important contributions in guiding further research and guiding researchers in the field.

This study aims to examine citation and publication related metrics of researches on distance education in higher education in both before the COVID-19 pandemic (16 January 2018 - 30 November 2019) and the pandemic (1 December 2019-14 September 2021) periods according to some performance variables. Given the framework of this extraordinary situation, this study aimed to determine the citation and publication related metrics of researches on distance education in higher education within a two-year period. In this context, the following research questions framed our study (questions address both the pre-pandemic period of January 2018 and November 2019 and the pandemic period of December 2019 and September 2021):

1. Who are the most cited researchers in publications on distance education in higher education?

2. Which are the most cited publications on distance education in higher education?

3. Which are the most cited journals on distance education in higher education?

4. Which are the most cited countries and universities of researchers in the publications on distance education in higher education?

\section{Methodology}

\subsection{Research Design}

The aim of this study is to examine COVID-19 effect on distance education in higher education in the preCOVID-19 pandemic (16 January 2018 - 30 November 2019) and the COVID-19 pandemic periods (1 December 2019-14 September 2021) by using a bibliometric analysis method. There are many techniques of bibliometric analysis, and in this study, citation and publication-based performance measurement techniques were preferred to answer the research questions (Donthu, 2021). The bibliometric analysis allows researchers to follow up the studies, institutions and scientific flow related to the determined scientific subject (Martí-Parreño et al., 2016). The research was conducted into two stages: 1) obtaining the data sets, 2) analyzing the data sets using VOSviewer.

\subsection{Obtaining Datasets}

Two separate searches were made to generate the data set. The reason for this was that data for pre-COVID19 pandemic (16 January 2018 - 30 November 2019) and the-COVID-19 pandemic periods (1 December 2019-14 September 2021) were desired to be obtained separately. Thus, it was possible to compare the data. First of all, Web of Science (WoS) database was searched using the following query for both periods: the pre-COVID-19 pandemic (16 January 2018 - 30 November 2019) and post-COVID-19 pandemic periods (1 December 2019-14 September 2021);

[("higher education" OR “universit*” OR “college” OR “undergrad*” OR “graduate” OR "postgrad*” OR "corporate training" OR "professional traning" OR "adult education" OR "vocational education" OR "medical school*" OR "medical student*" OR "dental education")] AND [(“online learning" OR "online teaching" OR "online education" OR "online course*" OR "open learning" OR "open and distance learning" OR "distance learning” OR “distance education" OR "elearning” OR "e-learning” OR "internet based learning" OR "internet based instruction" OR "internet based education" OR "virtual learning" OR "virtual education" OR "web based learning" OR "web based instruction" OR "web based education" OR "distance course*" OR "internet based course*" OR "web based course*" OR "web based class**" OR "internet based class*" OR "Online class*" OR "virtual class*" OR "online community" OR "Digital learning" OR "Digital education" OR "Digital instruction” OR "Digital course*” OR "Virtual learning" 
OR "Virtual education" OR "Virtual instruction" OR "Digital class*" OR "learning management system" OR "LMS" OR "MOOC*” OR "Massive Open Online Course*”)] NOT [("K-12" OR "kindergarden" OR "primary school" OR "middle school" OR "secondary school" OR "school" OR "high school" OR "reception" "R-12" "junior primary" OR "elementary school" OR "middle primary" OR "upper primary" OR "senior school")]

To avoid results that were not related to the purpose of the study, both searches were refined using limitations regarding the date range, publication type, language, index, and categories in the WoS database. Searches were conducted during the second week of September 2021 and only English articles were selected. From the first search it was obtained that total of 2567 articles for pre-COVID-19 pandemic (16 January 2018 - 30 November 2019) and a total of 4566 articles for the-COVID-19 pandemic period (1 December 2019-14 September 2021). As second criteria, document type was filtered by "journal articles" and indexes limited with "SSCI, SCI-EXPANDED, A\&HCI, and ESCI" for both periods. From the second search, it was obtained that total of 1572 articles for pre-COVID-19 pandemic (16 January 2018 - 30 November 2019) and a total of 3869 articles for the-COVID-19 pandemic periods (1 December 2019-14 September 2021). Finally, both search results were limited to "Education Educational Research" and "Education Scientific Disciplines" and filtered by "journal articles". From the last search it was obtained that total of 1322 articles for pre-COVID-19 pandemic (16 January 2018 - 30 November 2019) and a total of 2103 articles for the-COVID-19 pandemic period (1 December 2019-14 September 2021). Consequently, these two results formed the data sets of the study.

\subsection{The VOSviewer}

Citation and publication-based analysis was performed with VOSviewer to reveal the most cited researchers, publications, journals and universities between 2018-2021. Citation and publication-based analysis provides important data for identifying interdisciplinary similarities and differences between these variables (Biehl et al., 2006; Judge et al., 2007).

\subsection{Harzing's Publish or Perish}

Publish or Perish is a program that enables researchers to analyze academic citations from a variety of data sources, such as the Web of Science, Scopus, and Google Scholar. Publish or Perish can analyze different metrics, including the h-index, from raw citations (Harzing, 2016). In this study Publish or Perish was preferred to analyze the h-index for the performance analysis (Donthu, 2021).

\section{Findings}

\subsection{Most Cited Researchers in Publications on Distance Education in Higher Education}

The citation analysis identified the most cited researchers in the articles about distance education in higher education. In 16 January 2018 - 30 November 2019 (the pre-pandemic period), 13 researchers published at least four articles on distance education in higher education. To identify the most prolific researchers, the number of citations, number of publications, TLS value (calculated in VOSviewer), and h-index (calculated using Harzing's Publish or Perish software) were used. The citation analysis, which included all researchers with at least four publications, identified the top ten authors, who are ranked in Table 1 by number of citations. Accordingly, A. Bozkurt was clearly the most cited researcher during this period. The remaining researchers in the top ten of the pre-pandemic period, presented based on ranking criteria, included B.Rienties D. U. Bolliger, C. J. Ortagus, C. Stone, K. S. Jan, C. Lange, T. Sato, J. Costley, and E. VazquezCano. Nearly all of these top ten researchers worked in different universities. 


\section{Table 1.}

Most cited researchers on distance education in higher education in January 2018 and November 2019 (during the prepandemic period)

\begin{tabular}{|c|c|c|c|c|c|c|c|}
\hline Rank & Author & Country & University & Publications & Citations & h-index* & TLS \\
\hline 1 & A. Bozkurt & Turkey & Anadolu University & 5 & 72 & 4 & 0 \\
\hline 2 & B. Rienties & England & Open University & 5 & 69 & 5 & 0 \\
\hline 3 & D. U. Bolliger & America & Walden University & 4 & 58 & 3 & 0 \\
\hline 4 & J. C. Ortagus & America & University of Florida & 4 & 48 & 2 & 0 \\
\hline 5 & C. Stone & England & University of Newcastle & 4 & 46 & 3 & 0 \\
\hline 6 & K. S. Jan & Australia & Macquarie University & 4 & 27 & 3 & 0 \\
\hline 7 & C. Lange & Germany & Research Center Borstel & 5 & 22 & 3 & 1 \\
\hline 8 & T. Sato & Japan & University of Tsukuba & 4 & 21 & 3 & 0 \\
\hline 9 & J. Costley & Russia & National Research University & 5 & 18 & 3 & 1 \\
\hline 10 & E. Vazquez-Cano & Spain & $\begin{array}{l}\text { Universidad Nacional de } \\
\text { Educación a Distancia (UNED) }\end{array}$ & 4 & 10 & 3 & 1 \\
\hline
\end{tabular}

* Calculated using Harzing's Publish or Perish software.

Between 1 December 2019-14 September 2021 (the pandemic period), 17 researchers published at least four articles on distance education in higher education. To identify the most prolific researchers, the number of citations, number of publications, TLS value (calculated in VOSviewer), and h-index (calculated using Harzing's Publish or Perish software) were used. The citation analysis, which included all researchers with at least four publications, identified the top ten authors, who are ranked in Table 2 by number of citations. Accordingly, C. Herodotou was clearly the most cited researcher during this period. The remaining researchers in the top ten of the pandemic period, presented based on ranking criteria, included J. C. Bonk, Y. M. Doo, F. Martin, F. Han, D. Xu, A. S. Al-Adwan, J. Costley, M. Fanguy, and S. Lakhal. Nearly all of these top ten researchers worked in different universities.

Table 2.

Most cited researchers on distance education in higher education in December 2019 and September 2021 (during the pandemic period)

\begin{tabular}{|c|c|c|c|c|c|c|c|}
\hline Rank & Author & Country & University & Publications & Citations & h-index* & TLS \\
\hline 1 & C. Herodotou & Open University & England & 4 & 35 & 3 & 0 \\
\hline 2 & J. C. Bonk & Indiana University & America & 5 & 26 & 3 & 3 \\
\hline 3 & M. Y. Doo & Kangwon National University & Korea & 5 & 26 & 3 & 3 \\
\hline 4 & F. Martin & $\begin{array}{l}\text { University of North Carolina } \\
\text { Charlotte }\end{array}$ & America & 6 & 25 & 2 & 0 \\
\hline 5 & F. Han & Griffith University & America & 5 & 15 & 2 & 0 \\
\hline
\end{tabular}




\begin{tabular}{|c|c|c|c|c|c|c|c|}
\hline 6 & D. Xu & $\begin{array}{l}\text { University of California } \\
\text { Irvine }\end{array}$ & America & 5 & 15 & 2 & 0 \\
\hline 7 & A. S. Al-Adwan & Amman University & Jordan & 4 & 14 & 2 & 2 \\
\hline 8 & J. Costley & National Research University & Russia & 8 & 12 & 3 & 3 \\
\hline 9 & M. Fanguy & $\begin{array}{l}\text { Korea Advanced Institute of } \\
\text { Science and Technology }\end{array}$ & Korea & 4 & 10 & 3 & 3 \\
\hline 10 & S. Lakhal & Université de Sherbrooke & Kanada & 4 & 10 & 2 & 0 \\
\hline
\end{tabular}

* Calculated using Harzing's Publish or Perish software.

\subsection{Most Cited Publications on Distance Education in Higher Education}

The complete data set of studies published in the field of distance education in higher education during the pre-pandemic period (January 2018 - November 2019) included 1322 publications. Only 224 of these publications were cited ten times or more, as of the date of data collection for this study. To identify the most frequently cited publications, the number of citations were calculated using VOSviewer and researched using Google Scholar. The ten publications with the highest number of citations, as analyzed by VOSviewer, are listed in Table 3.

\section{Table 3.}

Most cited publications in January 2018 - November 2019 (during the pre-pandemic period) ranked by number of citations

\begin{tabular}{|c|c|c|c|c|c|}
\hline Rank & First Author & Journal & Title & $\begin{array}{l}\text { WoS } \\
\text { Citations }\end{array}$ & $\begin{array}{l}\text { Google } \\
\text { Scholar } \\
\text { Citations }\end{array}$ \\
\hline 1 & G. Makransky & L\&I & $\begin{array}{l}\text { Adding immersive virtual reality to a science lab simulation } \\
\text { causes more presence but less learning. }\end{array}$ & 155 & 396 \\
\hline 2 & W. A. Cidral & $\mathrm{C} \& \mathrm{E}$ & E-learning success determinants: Brazilian empirical study. & 117 & 293 \\
\hline 3 & C. Dziuban & IJETHE & Blended learning: the new normal and emerging technologies & 105 & 495 \\
\hline 4 & Y. J. Joo & $\mathrm{C} \& \mathrm{E}$ & $\begin{array}{l}\text { Examination of relationships among students' self- } \\
\text { determination, technology acceptance, satisfaction, and } \\
\text { continuance intention to use K-MOOCs. }\end{array}$ & 90 & 156 \\
\hline 5 & G. Makransky & ETRD & $\begin{array}{l}\text { A structural equation modeling investigation of the emotional } \\
\text { value of immersive virtual reality in education }\end{array}$ & 85 & 161 \\
\hline 6 & Al-Samarraie & SHE & $\begin{array}{l}\text { E-learning continuance satisfaction in higher education: a } \\
\text { unified perspective from instructors and students. }\end{array}$ & 66 & 173 \\
\hline 7 & F. Martin & IHE & $\begin{array}{l}\text { Student perception of helpfulness of facilitation strategies that } \\
\text { enhance instructor presence, connectedness, engagement and } \\
\text { learning in online courses. }\end{array}$ & 58 & 188 \\
\hline 8 & M. Bond & IJETHE & $\begin{array}{l}\text { Digital transformation in German higher education: student } \\
\text { and teacher perceptions and usage of digital media }\end{array}$ & 55 & 180 \\
\hline
\end{tabular}




\begin{tabular}{llllll}
\hline 9 & C. H. H. Tsay & C\&E & $\begin{array}{l}\text { Enhancing student learning experience with technology- } \\
\text { mediated gamification: An empirical study. }\end{array}$ & 54 \\
$10 \quad$ A. Watted & IHE & $\begin{array}{l}\text { Motivating factors of MOOC completers: Comparing between } \\
\text { university-affiliated students and general participants }\end{array}$ & 146 \\
\hline
\end{tabular}

* L\&I=Learning \& Instruction, C\&E=Computers \& Education, IJETHE= International journal of educational technology in Higher education, ETRD = Educational Technology Research and Development, SHE=Studies in Higher Education, IHE= Internet and Higher Education.

When Table 3 is examined which includes the most cited studies, it is seen that researchers conduct studies on different fields of distance education in higher education. In Table 3, the article titled "Adding immersive virtual reality to a science lab simulation causes more presence but less learning," published in Learning and Instruction in April 2019 with first author G. Makransky, appears to be the most cited during the prepandemic period. G. Maransky's second publication on the subject of immersive virtual reality is also ranked 5th in the table. It is determined that the research conducted by W. A. Cidral and Al-Samarraie on e-learning ranked second and sixth in the table, respectively.

The complete data set of studies published in the field of distance education in higher education during the pandemic period (1 December 2019-14 September 2021) included 2103 publications. Only 78 of these publications were cited ten times or more, as of the date of data collection for this study. To identify the most frequently cited publications, the number of citations were calculated using VOSviewer and researched using Google Scholar. The ten publications with the highest number of citations, as analyzed by VOSviewer, are listed in Table 4.

\section{Table 4.}

Most cited publications ranked by number of citations in December 2019 and September 2021 (during the pandemic period)

\begin{tabular}{|c|c|c|c|c|c|}
\hline Rank & First Author & Journal & Title & $\begin{array}{l}\text { WoS } \\
\text { Citations }\end{array}$ & $\begin{array}{l}\text { Google } \\
\text { Scholar } \\
\text { Citations }\end{array}$ \\
\hline 1 & M. A. Almaiah & EAIT & $\begin{array}{l}\text { Exploring the critical challenges and factors influencing the } \\
\text { E-learning system usage during COVID-19 pandemic }\end{array}$ & 75 & 242 \\
\hline 2 & G. J. Longhurst & ASE & $\begin{array}{l}\text { Strength, weakness, opportunity, threat (SWOT) analysis of } \\
\text { the adaptations to anatomical education in the United } \\
\text { Kingdom and Republic of Ireland in response to the Covid- } \\
19 \text { pandemic. }\end{array}$ & 65 & 142 \\
\hline 3 & N. Johnson & $\mathrm{ON}$ & $\begin{array}{l}\text { US Faculty and Administrators' Experiences and Approaches } \\
\text { in the Early Weeks of the COVID-19 Pandemic }\end{array}$ & 56 & 206 \\
\hline 4 & R. Khalil & BMCME & $\begin{array}{l}\text { The sudden transition to synchronized online learning during } \\
\text { the COVID-19 pandemic in Saudi Arabia: a qualitative study } \\
\text { exploring medical students' perspectives. }\end{array}$ & 42 & 135 \\
\hline 5 & $\begin{array}{l}\text { F. J. García- } \\
\text { Peñalvo }\end{array}$ & EKS & $\begin{array}{l}\text { Online assessment in higher education in the time of } \\
\text { COVID-19. }\end{array}$ & 40 & 99 \\
\hline 6 & M. Al-Balas & BMCME & $\begin{array}{l}\text { Distance learning in clinical medical education amid } \\
\text { COVID-19 pandemic in Jordan: current situation, } \\
\text { challenges, and perspectives }\end{array}$ & 35 & 111 \\
\hline
\end{tabular}




\begin{tabular}{|c|c|c|c|c|c|}
\hline 7 & H. M. Dai & $\mathrm{C} \& \mathrm{E}$ & $\begin{array}{l}\text { Explaining Chinese university students' continuance } \\
\text { learning intention in the MOOC setting: A modified } \\
\text { expectation confirmation model perspective. }\end{array}$ & 32 & 46 \\
\hline 8 & Alqahtani & ES & $\begin{array}{l}\text { E-learning critical success factors during the covid-19 } \\
\text { pandemic: A comprehensive analysis of e-learning } \\
\text { managerial perspectives. }\end{array}$ & 32 & 113 \\
\hline 9 & A.Y. Quezada & JET & $\begin{array}{l}\text { From bricks and mortar to remote teaching: A teacher } \\
\text { education program's response to COVID-19 }\end{array}$ & 25 & 86 \\
\hline 10 & $\begin{array}{l}\text { F. J. García- } \\
\text { Peñalvo }\end{array}$ & $\mathrm{CV}$ & $\begin{array}{l}\text { The COVID-19: The enzyme of the digital transformation of } \\
\text { teaching or the reflection of a methodological and } \\
\text { competence crisis in higher education? }\end{array}$ & 25 & 145 \\
\hline
\end{tabular}

* EAIT=Education and Information Technologies, ASE=Anatomical Sciences Education, ON=Online Learning, BMCME= BMC Medical Education, EKS=Education in the Knowledge Society, $C \& E=$ Computers \& Education, ES=Education Sciences, JET = Journal of Education for Teaching, $C V=$ Campus Virtuales, EKS=Education in the Knowledhe Society

Table 4 illustrates that distance education in higher education studies focused on Covid 19 pandemic were cited most frequently. The article titled "Exploring the critical challenges and factors influencing the Elearning system usage during COVID-19 pandemic," published in Education and Information Technologies in May 2020 with first author M. A. Almaiah, appears to be the most cited during the post-pandemic period. It is seen that the two studies, which are in the 4th and 6th place, are also included in the BMC Medical Education journal.

\subsection{Most Cited Journals on Distance Learning in Higher Education}

Citation analysis also identified the journals publishing the most research on distance education in higher education in 16 January 2018 - 30 November 2019 (during the pre-pandemic period). The analysis found that 32 out of 318 journals had at least ten citations in the research on distance education in higher education. To identify the most cited journals, the number of citations, number of publications, TLS value (calculated using VOSviewer), and h-index (calculated using Harzing's Publish or Perish software) were used. The ten journals with the highest number of citations are listed in Table 5.

\section{Table 5.}

Most Cited Journals in January 2018 - November 2019 (during the pre-pandemic period)

\begin{tabular}{|c|c|c|c|c|c|}
\hline Rank & Journal & Articles & Citations & h-index* & TLS \\
\hline 1 & Computers \& Education & 26 & 687 & 15 & 11 \\
\hline 2 & International Journal of Educational Technology in Higher Education & 22 & 389 & 10 & 9 \\
\hline 3 & British Journal of Educational Technology & 28 & 380 & 13 & 7 \\
\hline 4 & International Journal of Emerging Technologies in Learning & 46 & 300 & 9 & 4 \\
\hline 5 & Education and Information Technologies & 29 & 291 & 10 & 9 \\
\hline 6 & Online Learning & 36 & 277 & 9 & 12 \\
\hline
\end{tabular}




\begin{tabular}{llccc}
\hline 7 & Internet and Higher Education & 13 & 276 & 9 \\
8 & International Review of Research in Open and Distributed Learning & 49 & 257 & 7 \\
9 & BMC Medical Education & 23 & 188 & 9 \\
$10 \quad$ Australasian Journal of Educational Technology & 16 & 180 & 8 \\
\hline
\end{tabular}

Table 5 indicates that the journal with the highest number of citations and h-index during the pre-pandemic period was the Computers \& Education. Other leading journals included, in order, the International Journal of Educational Technology in Higher Education and British Journal of Educational Technology. Although International Review of Research in Open and Distributed Learning has more publications about distance education in higher education than Computer \& Education, Computer \& Education has a much higher citation count. Australasian Journal of Educational Technology is in last place in the table, with sixteen publications and 180 citations.

Citation analysis also identified the journals publishing the most research on distance education in higher education in 1 December 2019-14 September 2021 (the pandemic period). The analysis found that 52 out of 379 journals had at least ten citations in the research on distance education in higher education. To identify the most cited journals, the number of citations, number of publications, TLS value (calculated using VOSviewer), and h-index (calculated using Harzing's Publish or Perish software) were used. The ten journals with the highest number of citations are listed in Table 6.

\section{Table 6.}

Most cited journals in December 2019-September 2021 (during the pandemic period)

\begin{tabular}{|c|c|c|c|c|c|}
\hline Rank & Journal & Articles & Citations & h-index* & TLS \\
\hline 1 & Education and Information Technologies & 109 & 272 & 7 & 44 \\
\hline 2 & Online Learning & 67 & 188 & 6 & 19 \\
\hline 3 & Journal of Chemical Education & 59 & 187 & 6 & 10 \\
\hline 4 & Education Sciences & 54 & 174 & 7 & 12 \\
\hline 5 & International Journal of Emerging Technologies In Learning & 99 & 157 & 6 & 14 \\
\hline 6 & BMC Medical Education & 45 & 154 & 6 & 0 \\
\hline 7 & Computers \& Education & 25 & 128 & 7 & 4 \\
\hline 8 & Interactive Learning Environments & 41 & 116 & 7 & 5 \\
\hline 9 & International Journal of Educational Technology in Higher Education & 21 & 69 & 5 & 7 \\
\hline 10 & Revista Romaneasca Pentru Educatie Multidimensionala & 25 & 63 & 5 & 9 \\
\hline
\end{tabular}

Table 6 indicates that the journal with the highest number of citations and TLS value during the postpandemic period was Education and Information Technologies. Other leading journals included, in order, the Online Learning, Journal of Chemical Education and Education Sciences. Although the International Journal of Emerging Technologies In Learning had the greatest number of publications about distance 
education in higher education, it is ranked in $5^{\text {th }}$ place in the table based on its citation count. The Revista Romaneasca Pentru Educatie Multidimensionala is in last place in the table, with twenty-five publications and 63 citations. It was determined that the h-index values of the journals were quite close to each other.

\subsection{Most Cited Countries and Universities on Distance Education in Higher Education}

The citation analysis also determined the home countries and universities of the most cited researchers in the field of distance education in higher education in 16 January 2018 - 30 November 2019 (during the prepandemic period). The studies published during this period came from 104 different countries and 1401 universities. To identify the most cited universities and countries, the number of citations, number of publications, TLS value (calculated using VOSviewer), and h-index (calculated using Harzing's Publish or Perish) were used. The top ten most cited countries and universities in the field of distance education in higher education are presented in Table 7.

\section{Table 7.}

Top ten universities and countries on distance learning in in January 2018 - November 2019 (during the pre-pandemic period)

\begin{tabular}{lllllll}
\hline Rank & University & Country & Documents & Citations & $h$-index* & TLS \\
\hline 1 & King Saud University & Saudi Arabia & 7 & 177 & 7 & 0 \\
2 & University of South Africa & South Africa & 32 & 173 & 6 & 1 \\
3 & Anadolu University & Turkey & 13 & 141 & 6 & 1 \\
4 & Open University & England & 24 & 138 & 6 & 3 \\
5 & University of Central Florida & America & 7 & 134 & 4 & 1 \\
6 & University of Florida & America & 7 & 85 & 5 & 1 \\
7 & Indiana University & America & 7 & 80 & 5 & 0 \\
8 & University of Hong Kong & China & 10 & 79 & 7 & 0 \\
9 & Griffith University & Australia & 9 & 72 & 6 & 3 \\
10 & UNED - Universidad Nacional de Educación & a Spain & 13 & 70 & 8 & 0 \\
\hline
\end{tabular}

* Calculated using Harzing's Publish or Perish software.

Table 7 displays ten universities from eight different countries based on the number of citations. King Saud University in Saudi Arabia had the highest number of citations during the pre-pandemic period. In second place was the University of South Africa, while the USA's University of Central Florida, University of Florida and Indiana University took 5 th, $6^{\text {th }}$ and $7^{\text {th }}$ places, respectively. Anadolu University in Turkey ranked in $3^{\text {rd }}$ place and Open University in England ranked in $4^{\text {th }}$ place. Universities with the least number of documents in the table with 7 documents were King Saud University, University of Centrel Florida, University of Florida, and Indiana University. Moreover, the university with the most documents with 24 documents was seen as Open University. Although the h-index values of the universities are very close to 
each other, it is seen that the highest h-index value belongs to UNED - Universidad Nacional de Educación a Distancia, which is in the 10th rank.

The citation analysis also determined the home countries and universities of the most cited researchers in the field of distance education in higher education 1 December 2019-14 September 2021 (during the pandemic period). The studies published during this period came from 122 different countries and 2282 universities. To identify the most cited universities and countries, the number of citations, number of publications, TLS value (calculated using VOSviewer), and $h$-index (calculated using Harzing's Publish or Perish) were used. The top ten most cited countries and universities in the field of distance education in higher education are presented in Table 8.

\section{Table 8.}

Top ten universities and countries on distance education in higher education in December 2019-September 2021 (during the pandemic period)

\begin{tabular}{|c|c|c|c|c|c|c|}
\hline Rank & University & Country & Documents & Citations & $h$-index* & TLS \\
\hline 1 & Universiti Teknologi Malaysia & Malaysia & 13 & 66 & 5 & 0 \\
\hline 2 & Indiana University & America & 12 & 56 & 4 & 0 \\
\hline 3 & Open University & England & 18 & 43 & 5 & 0 \\
\hline 4 & Kazan Federal University & Russia & 11 & 36 & 3 & 2 \\
\hline 5 & University of California Irvine & America & 10 & 24 & 3 & 0 \\
\hline 6 & Hacettepe University & Turkey & 11 & 23 & 2 & 0 \\
\hline 7 & University of South Africa & South Africa & 24 & 23 & 3 & 0 \\
\hline 8 & Deakin University & Australia & 10 & 20 & 3 & 1 \\
\hline 9 & University of Illinois & America & 14 & 18 & 3 & 1 \\
\hline 10 & Pennsylvania State University & America & 15 & 15 & 2 & 0 \\
\hline
\end{tabular}

* Calculated using Harzing's Publish or Perish software.

Table 12 displays ten universities from seven different countries based on the number of citations. Universiti Teknologi Malaysia in the Malaysia had the highest number of citations during the pandemic period. In second place was the America's Indiana University. Four universities from the USA ranked in the top ten: University of California Irvine in $5^{\text {th }}$ place, University of Illinois in $9^{\text {th }}$ place, Pennsylvania State University in $10^{\text {th }}$ place. Hacettepe University in Turkey was ranked $6^{\text {th }}$. University of South Africa in South Africa ranked in $7^{\text {th }}$ place, while Deakin University in Australia ranked in $8^{\text {th }}$ place. Although the University of South Africa had the most publications during this period, it ranked in seventh place with 23 citations. It was determined that the h-index values of the journals were quite close to each other.

\section{Conclusion and Suggestions}

The present research sought to examine the studies on distance education at the higher education level both pre-pandemic and the COVID-19 pandemic. The study also aimed to identify the citation and publication 
related metrics on distance education in higher education both before and within two year after such an extraordinary situation. Based on these goals, the studies published pre-pandemic and the-pandemic were compared and interpreted through bibliometric analysis. This study first sought an answer to the research question of what were the most cited researchers in publications on distance education in higher education between January 2018 -November 2019 (during the pre-pandemic period) and December 2019-September 2021 (during the pandemic period). The analysis determined that A. Bozkurt, B. Rienties and D. U. Bolliger were, respectively, the most cited researchers in the pre-pandemic period. However, although A. Bozkurt (the author has 4 articles that received at least 4 citations during this period) is the most cited author, B.Rienties (h-index $=5)$ is the author with the highest $h$-index value. However, it is seen that there is no common point between the authors in terms of country and institution. In the pandemic data set, C. Herodotou ranked first place. J. C. Bonk ranked second place, while M. Y. Doo ranked third place. Moreover, all these three authors have the same h-index value (3) that means C. Herodotou, J. C. Bonk and M. Y. Doo have 3 articles that received at least 3 citations during this period. By the results of another study by Yavuz et al. (2021), in which the topic research and distance education studies in the WoS database were examined between 2020-2021, most cited authors were found Chen, Cong, Peng, Yang respectively. The difference may be due to the fact that this study mostly covers distance education studies in higher education and examines studies related to education in general. Similarly, at pre pandemic period results, it is also seen that there is no common point between the authors in terms of country and institution. However, it is noteworthy that Open University academicians were among the top three authors in both terms (Open University, 2021). Considering that Open University is an institution that only provides distance education, this is an expected result.

Second, this study sought to answer the question of which were the most cited publications on distance education in higher education between January 2018 and November 2019 (during the pre-pandemic period) and December 2019 and September 2021 (during the pandemic period). According to the analysis results, G. Makransky's "Adding immersive virtual reality to a science lab simulation causes more presence but less learning," published in Learning and Instruction in pre-pandemic period, was the most influential article in the field of distance education in higher education. G. Makransky's has another article that ranked fifth in the pre-pandemic period. It is seen that this author has done a study on "immersive virtual reality in education" in both studies. Zawacki-Richter et al. (2009) offers a Classification of Research Areas in distance education which was included covers a total of 15 research areas at upper (macro), middle (meso) and lower (micro) levels. It can be said that both studies of G. Makransky are suitable for the Educational technology research area, which is located in the meso level. As for the pandemic period, M. A. Almaiah's "Exploring the critical challenges and factors influencing the E-learning system usage during COVID-19 pandemic," published in Education and Information Technologies, was identified as the most influential article. It can be said that M. A. Almaiah's article is suitable for the "Instructional design; practices in education" research area in the micro level. It is seen that Covid-19 is effective in most of the articles published in the post-pandemic period. In the parallel of this finding, Yavuz et al (2021) revealed that covid19, online education, distance education, online learning, distance learning, pandemic, medical education keywords were most used in the articles. In the post-pandemic period, it can be stated that the studies were created mostly around a limited area and were aimed at case study. For this reason, the micro level of the classifications put forward by Zawacki-Richter et al. (2009) can be added as a research area in this extraordinary situation that the whole world has experienced.

Third, an answer was sought to the question of which were the most cited journals on distance education in higher education between January 2018 and November 2019 (during the pre-pandemic period) and December 2019 and September 2021 (during the pandemic period). The analysis shows that the most influential journal in 2018-2019, according to the number of citations, was the Computers \& Education (C\&E). C\&E received 687 citations from 26 publications about distance education in higher education in 2019 (Table 5). In 2019-2021, however, this journal dropped to 7th place in the rankings of the ten most- 
cited journals, receiving 128 citations from its twenty-five publications about distance education in higher education (Table 6). Moreover, of the top ten most influential publications in this area published in 20182019, the second (W. A. Cidral), fourth (Y.J.Joo), and nineth (C. H. H. Tsay) ranked studies were published in C\&E (Table 3). However, only one study, which ranked 7th in the list of most cited publications in 20202021, was published in C\&E (Table 4). The Computer \& Education's impact factor was 2.951 (Clarivate Analytics, 2020) while Google Scholar Metric lists its h-index as 109 and ranked it in first place among 20 journals in educational technology subcategories (Google Scholar, 2021). The most cited papers between 1989 to 2019 in the field of e-learning adoption theory, which were published in Computers \& Education, Computers in Human Behaviour, Online Information Review, and Educational Technology and Society (Mashroofa et al., 2019). In 2008 and 2017, co-citation analysis with studies in the field of online learning, blended learning, and distance education revealed that the top journals were Computers \& Education, The Internet and Higher Education, Journal of Asynchronous Learning Networks, Review of Educational Research, British Journal of Educational Technology, and Computers in Human Behavior (Park and Shea, 2020).

The analysis shows that the most influential journal in 2019-2021, according to the number of citations, was the Education and Information Technologies (EAIT). EAIT received 272 citations from 109 publications about distance education in higher education in 2020-2021 (Table 6). While the journal was ranked 5th in the pre-pandemic period in terms of citations, it rose to the 1st place in the pandemic period. Moreover, of the top ten most influential publications in this area published in 2019-2021, the first (M. A. Almaiah) ranked study with 75 citations were published in EAIT (Table 4). The Education and Information Technologies impact factor is 2.917 (Clarivate Analytics, 2020) while Google Scholar Metric lists its hindex as 52 and ranks it in fifth place among 20 journals in social sciences (Google Scholar, 2021). Another important finding was that the Journal of Chemical Education, which was not in the top ten most cited journals in 2018-2019, ranked 3rd in the 2020-2021 list with 59 publications and 187 citations. The Journal of Chemical Education was the most published journal in the top ten rankings, because the publication prepared a special issue for the COVID-19 pandemic in September 2020. Yavuz et al. (2021) aimed to reveal the profile of the studies conducted for distance education activities which found that the co-citation numbers of journals are listed as Computers \& Education, International Review of Research in Open and Distributed Learning, Lancet, Journal of Chemical Education, Sustainability and The Internet and Higher Education. Karaköse and Demirkol (2021) listed the first 6 journals in which the 100 most cited articles were published in the pandemic period (1 January-31 December 2020), respectively, Medical Education, Anatomical Sciences Education, Journal of Education for Teaching, Medical Teacher, European Journal of Teacher Education, Journal of Chemical Education. As a result of this research analysis and studies in the literature, it was seen that distance education studies in higher education were generally published in journals in the field of educational technology in the pre-pandemic period. In the pandemic period, these studies were also published in interdisciplinary journals.

Lastly, an answer was sought to the question of which countries and institutions were the most cited in the publications on distance education in higher education during January 2018 and November 2019 (the prepandemic period) and December 2019 and January-December 2021 (the pandemic period). The analysis identified that the most cited articles related to distance education in higher education in the pre-pandemic period were published by researchers working at Open University in England. The most cited country was the USA, followed by the UK, Malaysia, China, South Africa, Iran, and Turkey, respectively. The findings of the pandemic period are slightly different. The results of the analysis show that the most cited article on distance education in higher education was published by researchers at Indiana University in the USA. The USA was also the country with the most citations and the most publications during this period. Following the USA, the most cited countries were the UK, Turkey, Spain, and South Africa. The University of South Africa published the most articles in this area during the pandemic period, followed by Indiana University in the USA and Open University in England. Following the USA, the countries with the highest number of 
publications were South Africa, England, Turkey, and Spain, respectively. Similar studies in the literature show that Open University in England came to the forefront with its publications during the pre-pandemic and the pandemic periods (Amoozegar et al., 2018). The analysis of research institutions and countries enables scholars to find critical institutions in each field in order to seek possible cooperation and collaborations (Mohadab et al., 2020).

The study's contribution to the field is investigating how the Covid-19 pandemic affects publications in the field of distance education, examining the intellectual interactions and structural connections between research components by comparing citation and performance metrics. This study is limited to distance education in higher education studies published in WoS at 2018-2021. Therefore, expanding this work by using alternative databases (e.g., Scopus, ERIC, PsyInfo, PubMed) and including additional publication types (e.g., book chapters, conference papers) should also be considered. In addition, given that the pandemic affects all educational institutions, research trends can be revealed at different education levels (e.g., K-12, preschool, lifelong learning).

\section{References}

Amoozegar, A., Khodabandelou, R., \& Ebrahim, N. A. (2018). Major Trends in Distance Education Research: A Combination of Bibliometric and Thematic Analyze. International Journal of Information Research and Review, 5(2), 5352-5359. https://ssrn.com/abstract=3173980.

Biehl, M., Kim, H., \& Wade, M. (2006). Relationships among the academic business disciplines: a multimethod citation analysis. Omega, 34(4), 359-371. https://doi.org/10.1016/j.omega.2004.12.002 .

Bozkurt, A. (2019). From distance education to open and distance learning: A holistic evaluation of history, definitions, and theories. In Handbook of Research on Learning in the Age of Transhumanism (pp. 252-273). IGI Global. https://doi.org/10.4018/978-1-5225-8431-5.ch016

Bozkurt, A. (2020). Koronavirüs (Covid-19) pandemi süreci ve pandemi sonrası dünyada eğitime yönelik değerlendirmeler: Yeni normal ve yeni eğitim paradigması [The coronavirus (Covid-19) pandemic process and evaluations on education in the post-pandemic world: New normal and new education paradigm]. Açıöğretim Uygulamaları ve Araştırmaları Dergisi, 6(3), 112-142. https://dergipark.org.tr/en/download/article-file/1215818

Clarivate Analytics. (2020). Journal Citation Reports. https://jcr.clarivate.com/

Demirbilek, Y., Pehlivantürk, G., Özgüler, Z. Ö., \& Alp Meşe, E. (2020). COVID-19 outbreak control, example of ministry of health of Turkey. Turkish Journal of Medical Sciences, 50(SI-1), 489-494. https://doi.org/10.3906/sag-2004-187.

Donthu, N., Kumar, S., Mukherjee, D., Pandey, N., \& Lim, W. M. (2021). How to conduct a bibliometric analysis: An overview and guidelines. Journal of Business Research, 133, 285-296. https://doi.org/10.1016/j.jbusres.2021.04.070

El Mohadab, M., Bouikhalene, B., \& Safi, S. (2020). Bibliometric method for mapping the state of the art of scientific production in Covid-19. Chaos, Solitons \& Fractals, 139, 110052. https://doi.org/10.1016/j.chaos.2020.110052 .

Elçiçek, M. (2021). Tendencies in Turkey-Based Academic Studies on Distance Education during the COVID-19 Pandemic. Journal of Educational Technology and Online Learning, 4(3), 406-417. https://doi.org/10.31681/jetol.916038

Goktas, Y., Arpacik, O., Kucuk, S., Yildirim, G., Aydemir, M., Reisoğlu, İ., \& Telli, E. (2012). Educational Technology Research Trends in Turkey: A Content Analysis of the 2000-2009 Decade. Educational Sciences: Theory \& Practice, 12(1), 191-196. https://files.eric.ed.gov/fulltext/EJ978439.pdf . 
Google Scholar (2021). Google $\quad$ Scholar $\quad$ Metrics. https://scholar.google.com/citations?view_op=top_venues\&hl=tr\&vq=eng_educationaltechnology

Gurcan, F., Ozyurt, O., \& Cagitay, N. E. (2021). Investigation of Emerging Trends in the E-Learning Field Using Latent Dirichlet Allocation. The International Review of Research in Open and Distributed Learning, 22(2), 1-18. https://doi.org/10.19173/irrodl.v22i2.5358 .

Harzing, A. W. (2016). Publish or Perish. Harzing.com Research in International Management. Retrieved from https://harzing.com/resources/publish-or-perish .

Hodges, C., Moore, S., Lockee, B. Trust, T.\& Bond, A. (2021) The Difference Between Emergency Remote Teaching and Online Learning. https://er.educause.edu/articles/2020/3/the-difference-betweenemergency-remote-teaching-and-online-learning

Judge, T. A., Cable, D. M., Colbert, A. E., \& Rynes, S. L. (2007). What causes a management article to be cited-article, author, or journal?. Academy of Management Journal, 50(3), 491-506. https://doi.org/10.2307/20159868 .

Judge, T. A., Cable, D. M., Colbert, A. E., \& Rynes, S. L. (2007). What causes a management article to be cited-article, author, or journal?. Academy of management journal, 50(3), 491-506. https://doi.org/10.2307/20159868.

Karaköse, T., \& Demirkol, M. (2021). Exploring the emerging COVID-19 research trends and current status in the field of education: a bibliometric analysis and knowledge mapping. Educational Process: International Journal, 10(2), 7-21. https://dx.doi.org/10.22521/edupij.2021.102.1 .

Keegan, D. J. (1980). On defining distance education. Distance education, 1(1), 13-36. https://doi.org/10.1080/0158791800010102

Laato, S., Islam, A. N., Farooq, A., \& Dhir, A. (2020). Unusual purchasing behavior during the early stages of the COVID-19 pandemic: The stimulus-organism-response approach. Journal of Retailing and Consumer Services, 57, 102224. https://doi.org/10.1016/j.jretconser.2020.102224.

Martí-Parreño, J., Méndez-Ibáñez, E., \& Alonso-Arroyo, A. (2016). The use of gamification in education: a bibliometric and text mining analysis. Journal of computer assisted learning, 32(6), 663-676. https://doi.org/10.1111/jcal.12161.

Mashroofa, M. M., Jusoh, M., \& Chinna, K. (2019). Research trend on the application of "E-Learning Adoption Theory": A scientometric study during 2000-2019, based on Web of Science and SCOPUS. COLLNET Journal of Scientometrics and Information Management, 13(2), 387-408. https://doi.org/10.1080/09737766.2020.1729072.

Open University. (2021). https://www.open.ac.uk/

Park, H., \& Shea, P. (2020). A review of ten-year research through co-citation analysis: Online learning, distance learning, and blended learning. Online Learning, 24(2), 225-244. http://dx.doi.org/10.24059/olj.v24i2.2001.

Sangrà, A., Vlachopoulos, D., \& Cabrera, N. (2012). Building an inclusive definition of e-learning: An approach to the conceptual framework. The International Review of Research in Open and Distributed Learning, 13(2), 145-159. https://doi.org/10.19173/irrodl.v13i2.1161 .

Selçuk, Z., Palancı, M., Kandemir, M., \& Dündar, H. (2014). Tendencies of the Researches Published in Education and Science Journal: Content Analysis. Egitim ve Bilim, 39, 428-449. http://egitimvebilim.ted.org.tr/index.php/EB/article/view/3278 . 
Sun, P.-C., Tsai, R. J., Finger, G., Chen, Y.-Y., \& Yeh, D. (2008). What drives a successful e-Learning? An empirical investigation of the critical factors influencing learner satisfaction. Computers \& Education, 50(4), 1183-1202. https://doi.org/10.1016/j.compedu.2006.11.007

Talwar, M., Talwar, S., Kaur, P., Tripathy, N., \& Dhir, A. (2021). Has financial attitude impacted the trading activity of retail investors during the COVID-19 pandemic? Journal of Retailing and Consumer Services, 58, 102341. https://doi.org/10.1016/j.jretconser.2020.102341

UNESCO (2020). Guidance on Open Educational Practices during School Closures: Utilizing OER under COVID-19 Pandemic in line with UNESCO OER Recommendation. https://educacion.udd.cl/aprendizaje180/files/2020/12/UNESCO-IITE-Guidance-on-OpenEducational-Practices-during-School-Closures-2020.pdf .

Yavuz, M., Kayal1, B., \& Tutal, Ö. (2021). Trend of distance education research in the covid-19 period: A bibliometric and content analysis. Journal of Educational Technology and Online Learning, 4(2), 256-279. https://doi.org/10.31681/jetol.922682.

Zawacki-Richter, O., Backer, E. M. ve Vogt, S. (2009). Review of distance education research (2000 to 2008): Analysis of research areas, methods, and authorship patterns. The International Review of Research in Open and Distributed Learning, 10(6), 21-50. https://doi.org/10.19173/irrodl.v10i6.741. 